Jurnal Keperawatan Padjadjaran

ISSN 2338-5324 (print)

ISSN 2442-7276 (online)

Online di http://jkp.fkep.unpad.ac.id

DOI : $10.24198 / \mathrm{jkp}$

\title{
Determinant Factors of Depression in Patients with Coronary Heart Disease
}

\author{
Aan Nuraeni, Ristina Mirwanti, Anastasia Anna, Ikeu Nurhidayah \\ Faculty of Nursing Universitas Padjadjaran, Bandung, Indonesia \\ Corresponding email:aan.nuraeni@unpad.ac.id
}

Submitted: 26-06-2019 Accepted: 21-11-2019 Published: 05-12-2019

\begin{abstract}
Depression has been related to poor quality of life and recurrence in CHD patients. It is important to explore factors associated with the depression to prevent problems and to assist with appropriate intervention. Furthermore, the determinants of depression in CHD patients in Indonesia are still unknown. This study aimed to identify the determinants of depression in CHD patients in Indonesia. This study was a quantitative study with a cross-sectional approach. Samples were recruited from outpatient care in a referral hospital in Bandung using a consecutive sampling technique for $\mathrm{a}-2$ month period $(\mathrm{n}=101)$. Data were collected using a questionnaire package consisting of a demographic questionnaire, Beck Depression Index [BDI] (II), Zung Self-rating Anxiety Scale, Seattle Angina Questionnaire, and Spirituality Index of Well-Being. Data were analyzed using mean, frequency distribution, chi-square and logistic regression analysis. In terms of its association with depression in CHD patients, low spiritual well-being had the highest odds ratio [OR] $(\mathrm{OR}=9.3,95 \% \mathrm{CI}=2.968-29.451$, $\mathrm{p}<0.01$ ); non-anxious state and medication history had low ORs (sequentially OR $=0.2,95 \%$ CI $=0.067$ $0.644, \mathrm{p}<0.01 ; \mathrm{OR}=0.295 \% \mathrm{CI}=0.062-0.772, \mathrm{p}<0.01)$; PCI (percutaneous coronary intervention) with medication had the lowest $\mathrm{OR}$ value $(\mathrm{OR}=0.02,95 \% \mathrm{CI}=0.002-0.278, \mathrm{p}<0.01)$. On the other hand, unmarried status and male gender were identified as confounding variables. Low spiritual well-being was a major predictor of depression in CHD patients, whereas no anxiety, and history of medication, consist of CHD medication and reperfusion therapy contributed to a lower risk of depression. It is recommended to include strategies in improving spiritual well being and managing anxiety to reduce the risk of depression among CHD patients.
\end{abstract}

Keywords: Acute coronary syndrome, coronary heart disease, depression, determinant factors. 
Aan Nur'aeni: Determinant Factors of Depression in Patients with Coronary Heart Disease

\section{Introduction}

Coronary Heart Disease (CHD) could induce psychological problems to its patients. One of those problems is depression. Depression which has been experienced by CHD patients can affect the development of CHD disease and quality of life. Depression can affect the cardiovascular directly by increasing the frequency of heart rate and blood pressure. This condition will increase the oxygen demand and decrease the oxygen supply in the myocardium (Glozier et al., 2013). Furthermore, it will increase the risk of angina or recurrence. Depression also contributes to the formation of thrombosis (Huffman, Celano, \& Januzzi, 2010; Lichtman et al., 2014; Williams, Rogers, Wang, \& Ziegelstein, 2014) resulting in the formation of new blockages in the coronary arteries and generate recurrence. These conditions can further aggravate the patient's psychological and adversely affect the deterioration of the disease. More over a meta analysis study suggested that depression was a risk factor for death in CHD patients(Wu \& Kling, 2016).

Depression has a worse effect on reducing the quality of life in CHD patients than other psychosocial problems such as anxiety. Based on a previous study on CHD patients, it was known that patients with depression had a lower quality of life 5.4 times lower than patients who were not depressed, while anxiety in patients with CHD decreased the quality of life of patients as much as 4.7 times (Nuraeni, Mirwanti, Anna, \& Prawesti, 2016). The study also found that depression had the greatest impact on the quality of life compared to other factors, so the incidence of depression should be prevented and should be handled better.

Several factors that affected the incidence of depression based on previous research were anxiety, percutaneous coronary intervention (PCI) and spiritual wellbeing (Gu, Zhou, Zhang, \& Cui, 2016; Nuraeni \& Mirwanti, 2017; O'Neil et al., 2016) marital status, education level, gender, and poor health condition (Altino, Nogueira-Martins, de Barros, \& Lopes, 2017). However, the relationship of various factors, such as demographic data, anxiety, spiritual wellbeing, angina frequency and physical limitations to the incidence of depression, and which factors have the greatest effect on depression in CHD patients in Indonesia remains unclear. In addition, an overview of the proportion of depression events with treatment options in patients with CAD, in previous studies, especially in Indonesia, is also unclear. Differences in cultural background, social norms, demographic conditions, and health services enable different results on depression and related factors.

The severity of complications that may occur in CHD patients due to depression must be considered and anticipated immediately with appropriate intervention. Investigation factors related to the incidence of depression can be used as the information for anticipating depression incidences. This study was held to identify factors related to depression on CHD patients in Indonesia particularly West Java. These factors were anxiety, spiritual well-being, marital status, and several factors related to health conditions, such as physical limitations, and frequency of angina, and factor related to medication history (medication, PCI with medication, and CABG with medication). This study was expected to provide an overview of the factors that contribute to the occurrence of depression in CHD patients so that efforts to prevent the problems can be done more precisely and effectively.

\section{Method}

Data used in this analysis was derived from the "Depression and Frequency of Angina Patients with Acute Coronary Syndrome" study. The study used a descriptive quantitative method with a cross-sectional approach (Lismawaty, Nuraeni, \& Rapiah, 2015). The population of the study was patients with CHD who had a history of stable angina, unstable angina, ST myocardial infarction elevation, non-ST elevation myocardial infarction. The sample of the study was taken using a consecutive sampling technique from outpatient care in a referral hospital in Bandung with the criteria that the patient had undergone care at least for a month. Data collection was conducted for 2 months from April to June 2015 and 
Aan Nur'aeni: Determinant Factors of Depression in Patients with Coronary Heart Disease

obtained 101 respondents who were qualified and filled the instrument completely.

There were 10 variables measured from the research, with depression as a dependent variable and 9 independent variables (predictors) i.e. age, sex, marital status, income level, anxiety, spiritual well-being, physical limitations, angina frequency, and medical history. Depression in this study was measured using an instrument of Beck Depression Inventory II (BDI-II) Indonesian version had been tested for construct validity by validation value $\mathrm{r}=0,55, \mathrm{p}<0,01$ and reliability measured with alpha equal to 0,90 Cronbach (Ginting, Näring, Van Der Veld, Srisayekti, \& Becker, 2013). Depression was categorized into 2 groups i.e. BDI (II) score $\leq$ 13 included in no depression and BDI II score $\geq 13$ as depression. The Spirituality Index of Well-Being (SIWB) is used to measure the level of spiritual well-being. This instrument had been used in Indonesia with validity test result $r=0.373-0.614$ ( $\mathrm{r}$ table 0.195 ) and reliability $0.805-0.825$ (Nuraeni et al., 2016). Spiritual well-being was categorized by mean score. If the SIWB score of respondents was greater than SIWB mean score of all respondents then it was categorized as having high spiritual well-being. The mean score of SIWB in this study was 49.14. The Zung Self-rating Anxiety Scale (SAS) was used to measure anxiety. It had a validity score of 0.66 , which increased to 0.74 in patients diagnosed with an anxiety disorder and had an alpha cronbach of 0.85 (McDowell, 1989). This variable was categorized as not anxious if the score less than 44 and anxious if the score was in the range of $44-100$. Seattle Angina Questionnaire was used to measure the physical limitations and frequency of angina. The reliability for the dimensions of physical limitations was 0.83 , and for the dimension of angina, the frequency was 0.76 (Spertus, et al., 1995). Physical and anginal variability were categorized into mild (50$100)$ and moderate-severe (0-49) score.

Characteristics of the respondents (age, sex, income level, and marital status), depression, spiritual well-being, anxiety, physical limitations, and frequency of angina presented descriptively. Bivariate analysis was tested using the chi-square test and the variable relation model with depression was analyzed by logistic regression. The questionnaires and data collection process had undergone an ethical review and had obtained ethical clearance from the Health Research Ethics Committee of Hasan Sadikin Hospital, through a recommendation letter of ethical clearance Number: LB.04.01 /A05/ $\mathrm{EC} / 106 / \mathrm{IV} / 2015$.

\section{Results}

Table 1 Demographic and Depressive Characteristics of Respondents

\begin{tabular}{|c|c|c|c|c|c|c|c|c|}
\hline \multirow[t]{2}{*}{ Characteristics } & \multirow[t]{2}{*}{$\begin{array}{l}\text { Frequency } \\
\text { (f) }\end{array}$} & \multirow[t]{2}{*}{$(\%)$} & \multicolumn{4}{|c|}{$\begin{array}{c}\text { BDI-II } \\
\text { Score -freq }(\mathrm{N}=101)\end{array}$} & \multirow[t]{2}{*}{$\begin{array}{l}\text { Depression } \\
\text { Mean(SD) }\end{array}$} & \multirow[t]{2}{*}{ p-value } \\
\hline & & & $\leq 13$ & $\%$ & $>13$ & $\%$ & & \\
\hline \multicolumn{9}{|l|}{ Depression scores } \\
\hline$\leq 13$ & 60 & 59.4 & 60 & 100 & - & & $12,25(8,3)$ & - \\
\hline$>13$ & 41 & 40.6 & - & & 41 & 100 & & \\
\hline \multicolumn{9}{|l|}{ Age } \\
\hline $0-60$ years old & 60 & 59.4 & 35 & 58.3 & 25 & 41.6 & $12,77(7,94)$ & 0.791 \\
\hline$>60$ years old & 41 & 40.6 & 25 & 60.98 & 16 & 39.2 & $11,5(8,97)$ & \\
\hline \multicolumn{9}{|l|}{ Gender } \\
\hline Male & 78 & 77.2 & 49 & 62.8 & 29 & 37.2 & $15,8(10,3)$ & 0.198 \\
\hline Female & 23 & 22.8 & 11 & 47.8 & 12 & 52.2 & $11,2(7,4)$ & \\
\hline \multicolumn{9}{|l|}{ Marital status : } \\
\hline Married & 91 & 90.1 & 56 & 61.5 & 35 & 38.5 & $7,1(4,9)$ & 0,188 \\
\hline Not-married & 10 & 9.9 & 4 & 40 & 6 & 60 & 17(9) & \\
\hline
\end{tabular}


Aan Nur'aeni: Determinant Factors of Depression in Patients with Coronary Heart Disease

\begin{tabular}{|c|c|c|c|c|c|c|c|c|}
\hline \multicolumn{9}{|l|}{ incomes/month } \\
\hline $1-2,9$ million $\mathrm{Rp}$ & 68 & 67.3 & 40 & 58.8 & 28 & 41.2 & $12,8(8,7)$ & \multirow[t]{2}{*}{0,864} \\
\hline $\begin{array}{l}\geq 3 \text { million Rp. } \\
\text { anxious : }\end{array}$ & 33 & 32.7 & 20 & 60.6 & 13 & 39.4 & $11,1(7,5)$ & \\
\hline anxious (low-severe) & 57 & 56.4 & 27 & 47.4 & 30 & 52.6 & $14,15(8,6)$ & \multirow[t]{2}{*}{$0,005^{* *}$} \\
\hline Not-anxious & 44 & 43.6 & 33 & 75 & 11 & 25 & $10,1(7,6)$ & \\
\hline \multicolumn{9}{|l|}{ Physical limitations : } \\
\hline Minimal-low & 98 & 97 & 58 & 59.2 & 40 & 40.8 & $12,2(8,4)$ & \multirow[t]{2}{*}{0,795} \\
\hline Moderate-severe & 3 & 3 & 2 & 66.7 & 1 & 33.3 & $14,0(4,3)$ & \\
\hline \multicolumn{9}{|l|}{ Spiritual-wellbeing : } \\
\hline Low & 53 & 52.5 & 20 & 37.7 & 33 & 62.3 & $13(8,4)$ & \multirow[t]{2}{*}{$0,000 * *$} \\
\hline High & 48 & 47.5 & 40 & 83.3 & 8 & 16.7 & $5,9(3,8)$ & \\
\hline \multicolumn{9}{|l|}{ Frequency of angina } \\
\hline Minimal-low & 90 & 89.1 & 55 & 61.1 & 35 & 38.9 & $11,6(7,6)$ & \multirow[t]{2}{*}{0,318} \\
\hline Moderate-severe & 11 & 10.9 & 5 & 45.5 & 6 & 54.5 & $17,8(11,9)$ & \\
\hline \multicolumn{9}{|l|}{$\begin{array}{l}\text { Medical treatment } \\
\text { history }\end{array}$} \\
\hline Medication & 60 & 59.4 & 34 & 56.7 & 26 & 43.3 & $12,67(7,6)$ & \multirow[t]{3}{*}{$0,005^{*}$} \\
\hline PCI and medication & 16 & 15.9 & 15 & 93.75 & 1 & 6.25 & $6,12(5,9)$ & \\
\hline $\begin{array}{l}\text { CABG (with or } \\
\text { without PCI) and } \\
\text { medication }\end{array}$ & 25 & 24.8 & 11 & 44 & 14 & 56 & $15.2(9.5)$ & \\
\hline
\end{tabular}

Table 2 Final Model Factors Associated with Depression in Coronary Heart Disease Patients

\begin{tabular}{llccc}
\hline \multicolumn{1}{c}{ Variables } & \multicolumn{1}{c}{ Categories } & \multicolumn{2}{c}{ Depression on CHD Patients } \\
& & p-value & OR & 95\% CI \\
\hline Gender & Male & 0.247 & 2.314 & $0.560-5.570$ \\
Marital status & Not-married & 0.076 & 6.621 & $0.820-53.483$ \\
Spiritual-wellbeing & Low & $0.000^{* *}$ & 9.349 & $2.968-29.451$ \\
Anxious & Not-anxious & $0.007^{* *}$ & 0.207 & $0.067-0.644$ \\
Medication & CABG and & $0.006^{* *}$ & & \\
treatment history & medication & & & $0.062-0.772$ \\
& Medication & $0.018^{*}$ & 0.218 & $0.002-0.278$ \\
\hline
\end{tabular}

The results showed that there were three variables that had significant differences in depression status; The variables were anxiety, spiritual wellbeing, and type of medication. The proportion of patients with mild to severe anxiety who experienced depression was more than a half $(52.6 \%)$ while patients who were not anxious accounted for only $25 \%$ with depression; and only $16.7 \%$ patients with high spiritual well-being who experience depression, this was different from patients who had low spiritual wellbeing. The incidence of depression was the majority, it was accounted for $62.3 \%$. The results of the analysis are shown in table 1.

Based on an analysis of the factors studied, including age, sex, marital status, income level, anxiety, spiritual well-being, physical limitations, angina frequency, and medical treatment history, that meet the requirements to be included in the multivariate analysis were gender, marital status, anxiety, spiritual- 
Aan Nur'aeni: Determinant Factors of Depression in Patients with Coronary Heart Disease

wellbeing and medical treatment history. These factors then were involved in the investigation to identified the final model.

The final model of logistic regression analysis showed that not anxious and medication treatment history; and PCI with medication as a predictor variable of low risk of depression and low spiritual well-being factor as a predictor of an increased risk of depression while male and unmarried status variables became confounding variables.

Low spiritual well-being had the highest OR which was 9.349 (9.3). It means that CHD patients with low spiritual well-being had 9 times more risk of depression than those with high spiritual well-being with a probability of depression $90.34 \%$. Meanwhile, the nonanxious variable had a low OR of 0.2 meaning that CHD patients who were not anxious had 0.2 -time depression risk than an anxious CHD patient with a $16 \%$ probability of depression. The same OR as the non-anxious variable occurred in medication history $(\mathrm{OR}=$ 0.2 ). It means that the medication history had a $16 \%$ probability of depression compared to patients who had undergone CABG. PCI with medication was the variable with the lowest OR (0.02) means that CHD patients with a history of treatment had a $2 \%$ risk of depression compared to those who had undergone $\mathrm{CABG}$ treatment history and medication. However, those risks were also affected by gender and marital status as confounding factors. The final model obtained from the analysis is illustrated in Table 2.

\section{Discussion}

Based on the results, the factors that had the highest average depression score were in the category of medium to severe angina which was 17.8 $(\mathrm{SD}=11.9)$. Whereas based on the distribution frequency, more than three-fifths $(62.3 \%)$ of respondents with low spiritual well-being experienced depression, this factor had the highest incidence of depression compared to other factors. The score of 17.8 in BDI-II was included in the range of the mild depression (mild depression range score 14-19). This means that the average depression score of each category lies in mild depression. However, depression in this category might increase to moderate and severe levels, if it is not given appropriate intervention. The results of this study indicated that depression experienced by CHD patients was in the mild category but with a high-frequency occurrence. These results provided an overview of the need for serious effort to prevent an increase in depression levels thus unexpected adverse outcomes can be avoided (Huffman et al., 2010; Kim et al., 2017; Lichtman et al., 2014).

Spirituality can be a source of coping with patients with chronic depression. patients with chronic diseases benefit greatly from practicing their religious practices and beliefs, especially in individuals who were able to maintain hope, realized the meaning of life, and had peace and use it as a source of coping (Lucette, Ironson, Pargament, \& Krause, 2016). Spirituality and religiosity capable of reducing depression is a spirituality that is generating or maintaining hope, belief, and peacefulness (Bekelman et al., 2007; Lucette et al., 2016). It could be obtained by individuals who have good spiritual wellbeing. Other studies conducted on patients with heart failure showed similar results that high spiritual well-being corresponds to a decrease in depression (Bekelman et al., 2007). Furthermore, Warber et al in a study on CHD patients found that spiritual intervention can be used to increase hope and reduces depression (Warber et al., 2011).

Religion is a part of spirituality, religious dogma, as well as religious practice, can help a person understand spirituality (Burkhardt, M. A., \& Nagai-Jacobson, 2005). Islam is a religion embraced by almost all respondents in this study. According to the view of Islam, physical pain or suffering must be seen as a temptation given by God, and man are required to endeavor, be patient, pray and hope only to God (Yaacob, 2013). If someone has had this view then they will have peace and serenity. Based on the results of the study, most respondents have low spiritual-wellbeing $(52.5 \%)$, this suggests that the majority of patients in this study had not been able to live out their religion and gain an understanding of the meaning and purpose of life, hope, and peace (spirituality). The Management of CHD patients following acute phase in 
Aan Nur'aeni: Determinant Factors of Depression in Patients with Coronary Heart Disease

this population mostly focused on physical aspects including cardiac rehabilitation as well as lifestyle arrangements, but the spiritual aspect to improve the spiritual wellbeing had not been done optimally. In fact, the results of research proved that CHD patients in this study required better spiritual intervention in addition to physical aspects.

Anxiety is a psychosocial problem that is often experienced by CHD patients and associated with a poor prognosis of the illness. Anxiety trigger factors are often difficult to avoid, but the most important is the ability to control anxiety, particularly for CHD patients. Information about the risk of anxiety as well as how to reduce or control anxiety becomes important to be delivered to CHD patients so that patients are able to manage anxiety independently after returning home. This ability to control anxiety becomes very essential because anxiety related to the increase of angina frequency (Rachmi, Nur'aeni, \& Mirwanti, 2018) and the increase in the frequency of angina affects the functional status of patients, where according to Shin, Hwang, Jeong, and Lee (2013), functional status in CAD patients significantly influences depression. Furthermore, Nuraeni and Mirwanti (, (2017) stated that anxiety is directly related to depression in CAD patients.

The next factor was patients undergoing CABG with medications; and PCI with medication. The results showed that patients undergoing medication and PCI therapy had a lower risk of depression than patients who underwent $\mathrm{CABG}$. $\mathrm{CABG}$ is a reperfusion therapy through surgery, to open coronary blockages bypassing arteries that block the supply of blood to the heart using blood vessels from other parts of the body (Stillwell, 2011). CABG is major surgery, contrary with PCI. PCI is not a surgical procedure, the recovery process of PCI might be shorter and lighter compared to CABG.

Prior studies showed that in the beginning phase, PCI has a higher level of recovery than CABG. It was stated that the quality of life of patients undergoing PCI in the first month increased more rapidly than $\mathrm{CABG}$ patients and slightly changed in the three months post-therapy (Doering, Rumpold, Oldridge, \& Benzer, 2006). Other than that, the mortality rate in $\mathrm{CABG}$ was also higher than PCI at one-year post-therapy (SzygułaJurkiewicz, B., Wilczek, K., Przybylski, R., Pacholewicz, J., Trzeciak, P., Styn, T., Zembala, M., Poloński, 2004). Furthermore, stroke was more common in patients undergoing $\mathrm{CABG}$ than $\mathrm{PCI}$ at 12 months post reperfusion therapy. However, there was different finding from a study which stated that $\mathrm{CABG}$ was able to lower the risk of major adverse cardiac or cerebrovascular events (MACCE) higher than PCI (Feldman et al., 2009). These conditions explain that the risk of depression in patients with $\mathrm{CABG}$ is higher than patients who undergo PCI, although at low risk, in the first year after therapy. It's also implied that nurses or other health workers could anticipate depression in CHD patients by giving more attention on physical, psychological and spiritual needs particularly in patients undergoing $\mathrm{CABG}$ therapy in the first year after therapy.

This study also discovered the confounding factors that could influence depression in CHD patients. Those factors were gender and marital status. Both of these factors can make a difference in the risk of depression. Based on the result of logistic regression, it can be predicted that CHD patients with low spiritual wellbeing status may be at greater risk of depression if the patient is male and unmarried, whereas in female and married patients it is likely to have a lower risk of depression.

This study had several weaknesses. This study did not explain the medication used by the patients. Other than that, this study did not state how long the patients were diagnosed and were undergoing treatment with medication therapy or reperfusion therapy, whereas based on the results of previous research it was known that the duration of any treatment can determine the outcome of the respondents and may have an effect on the risk of depression.

\section{Conclusion}

Low spiritual well-being was a major predictor of depression in CHD patients. It was also known that not-anxious, as well as medical history with medication or 
Aan Nur'aeni: Determinant Factors of Depression in Patients with Coronary Heart Disease

reperfusion therapy, might determine a lower risk of depression. However, patients with CABG need more attention because they had a higher risk of depression than other therapeutic options even at very low risk of depression. Prevention of the incidence of depression can be done through efforts to improve spiritual wellbeing and anxiety management in CHD patients.

We thank Ima Lismawaty for helping to collect data for analysis in this manuscript.

We guarantee that the manuscript is original, has never been published elsewhere and will not be submitted to another publisher.

\section{References}

Altino, D. M., Nogueira-Martins, L. A., de Barros, A. L. B. L., \& Lopes, J. d. L. (2017). Predictive Factors of Anxiety and Depression in Patients with Acute Coronary Syndrome. Archives of Psychiatric Nursing, 31(6), 549-552. https://doi.org/10.1016/j. apnu.2017.07.004.

Bekelman, D. B., Dy, S. M., Becker, D. M., Wittstein, I. S., Hendricks, D. E., Yamashita, T. E., \& Gottlieb, S. H. (2007). Spiritual well-being and depression in patients with heart failure. Journal of General Internal Medicine, 22(4), 470-477. https://doi. org/10.1007/s11606-006-0044-9.

Burkhardt, M. A., \& Nagai-Jacobson, M. G. (2005). Spirituality and Health. In Holistic Nursing A Handbook For Practice (Fourth ed.). Massachussetts: Jones and Bartlett Publisher Inc.

Cheok, F., Schrader, G., Banham, D., Hons, B. A., Marker, J., \& Hordacre, A. (2003). Identification, course, and treatment of depression after admission for a cardiac condition: Rationale and patient characteristics for the Identifying Depression As a Comorbid Condition (IDACC ) project. The American Heart Journal, 8703(03), 978-984. https://doi.org/10.1016/S00028703(03)00481-2.

Doering, S., Rumpold, G., Oldridge, N., \& Benzer, W. (2006). Determinants of health- related quality of life in patients with coronary artery disease Stefan Ho. European Society of Cardiology, 13(3), 398-406.

Feldman, T. E., Brand, M. Van Den, Bass, E. J., Dyck, N. Van, Leadley, K., Dawkins, K. D., ... Investigators, S. (2009). Percutaneous Coronary Intervention versus CoronaryArtery Bypass Grafting for Severe Coronary Artery Disease. The New England Journal of Medicine, 360(10), 961-972.

Ginting, H., Näring, G., Van Der Veld, W. M., Srisayekti, W., \& Becker, E. S. (2013). Validating the Beck Depression InventoryII in Indonesia's general population and coronary heart disease patients. International Journal of Clinical and Health Psychology, 13(3), 235-242. https://doi.org/10.1016/ S1697-2600(13)70028-0.

Glozier, N., Tofler, G., Colquhoun, D. M., Bunker, S. J., Clarke, D. M., Hare, D. L., ... Branagan, M. G. (2013). Psychosocial risk factors for coronary heart disease. The Medical Journal of Australia, 23(August), 1-6. https://doi.org/10.5694/mja13.10440.

Gu, G., Zhou, Y., Zhang, Y., \& Cui, W. (2016). Increased prevalence of anxiety and depression symptoms in patients with coronary artery disease before and after percutaneous coronary intervention treatment. BMC Psychiatry, 16(1), 259. https://doi.org/10.1186/s12888-016-0972-9.

Huffman, J. C., Celano, C. M., \& Januzzi, J. L. (2010). The relationship between depression, anxiety, and cardiovascular outcomes in patients with acute coronary syndromes. Neuropsychiatric Disease and Treatment, 6, 123-136. Retrieved from http://www.ncbi. nlm.nih.gov/pubmed/20505844.

Kim, Y., Soffler, M., Paradise, S., Jelani, Q., Dziura, J., Sinha, R., \& Safdar, B. (2017). Depression is associated with recurrent chest pain with or without coronary artery disease: A prospective cohort study in the emergency department. American Heart Journal, 191 , 47-54. https://doi.org/10.1016/j. ahj.2017.06.003. 
Aan Nur'aeni: Determinant Factors of Depression in Patients with Coronary Heart Disease

Lichtman, J. H., Froelicher, E. S., Blumenthal, J. A., Carney, R. M., Lynn, V., Frasure-smith, N., ... Wulsin, L. (2014). Depression as a Risk Factor for Poor Prognosis Among Patients With Acute Coronary Syndrome: Systematic Review and Recommendations. https://doi. org/10.1161/CIR.0000000000000019.

Lismawaty, I., Nuraeni, A., \& Rapiah, I. (2015). Tingkat Depresi dan Frekuensi Angina Pasien dengan Sindrom Koroner Akut. (Depression Rate and Angina Frequency in Patients with Acute Coronary Syndrome). In Simposium Nasional Keperawatan Kritis. Bandung. Retrieved from http://simnas.fkep. unpad.ac.id/?page_id=20.

Lucette, A., Ironson, G., Pargament, K. I., \& Krause, N. (2016). Spirituality and Religiousness are Associated With Fewer Depressive Symptoms in Individuals With Medical Conditions. Psychosomatics, 57(5), 505-513. https://doi.org/10.1016/j. psym.2016.03.005.

McDowell, I. (1989). Measuring Health - a Guide To Rating Scales and Questionnaires. The Journal of the Canadian Chiropractic Association ,33. Oxford University Press. https://doi. org/10.1179/108331900786166731.

Nuraeni, A., \& Mirwanti, R. (2017). Hubungan Cemas dan Depresi pada Pasien dengan Penyakit Jantung. Medisains, $X V(2)$, $10-16$.

Nuraeni, A., Mirwanti, R., Anna, A., \& Prawesti, A. (2016). Faktor yang Memengaruhi Kualitas Hidup Pasien dengan Penyakit Jantung Koroner. (Relationship between anxiety and depression in patients with heart disease). Jurnal Keperawatan Padjadjaran, 4(2).

O'Neil, A., Fisher, A. J., Kibbey, K. J., Jacka, F. N., Kotowicz, M. A., Williams, L. J., ... Pasco, J. A. (2016). Depression is a risk factor for incident coronary heart disease in women: An 18-year longitudinal study. Journal of Affective Disorders, 196, 117-124. https:// doi.org/10.1016/J.JAD.2016.02.029.
Rachmi, F., Nur'aeni, A., \& Mirwanti, R. (2018). Kecemasan Berhubungan Dengan Frekuensi Agina: Studi Korelatif Pada Pasien Pasca Sindrom Koroner Akut. (Anxiety Associated with Frequency of Angina: Correlative Study in Patients After Acute Coronary Syndrome). Medisains: Jurnal Ilmiah Ilmu-Ilmu Kesehatan, 16(1-7).

Shin, E. S., Hwang, S. Y., Jeong, M. H., \& Lee, E. S. (2013). Relationships of factors affecting self-care compliance in acute coronary syndrome patients following percutaneous coronary intervention. Asian Nursing Research, 7(4), 205-211. https://doi. org/10.1016/j.anr.2013.10.003.

Spertus, J. A., Winder, J. A., Dewhurst, T. A., Deyo, R. A., Prodzinski, J., McDonnell, M., \& Fihn, S. D. (1995). Development and evaluation of the Seattle Angina questionnaire: A new functional status measure for coronary artery disease. Journal of the American College of Cardiology, 25(2), 333-341. https://doi.org/10.1016/07351097(94)00397-9.

Stillwell, S. B. (2011). Pedoman Keperawatan Kritis (Critical Nursing Guidelines) (3rd ed.). Jakarta: Penerbit Buku Kedokteran ECG.

Szyguła-Jurkiewicz, B., Wilczek, K., Przybylski, R., Pacholewicz, J., Trzeciak, P., Styn, T., Zembala, M., Poloński, L. (2004). Percutaneous and surgical revascularization in acute coronary syndromes without persistent ST segment elevation. One-year outcome of 361 patients assigned to early invasive strategy ( Article ) [ Rewaskularyzacja przezskórna i chirurgiczna w ostrych zesp. Przeglad Lekarski, 61(12), 1295-1300.

Warber, S. L., Ingerman, S., Moura, V. L., Wunder, J., Northrop, A., Gillespie, B. W., ... Rubenfire, M. (2011). Healing the heart: A randomized pilot study of a spiritual retreat for depression in acute coronary syndrome patients. Explore: The Journal of Science and Healing, 7(4), 222-233. https://doi. org/10.1016/j.explore.2011.04.002.

Williams, M. S., Rogers, H. L., Wang, N. Y., \& Ziegelstein, R. C. (2014). Do platelet-derived 
Aan Nur'aeni: Determinant Factors of Depression in Patients with Coronary Heart Disease

microparticles play a role in depression, inflammation, and acute coronary syndrome? Psychosomatics, 55(3), 252-260. https://doi. org/10.1016/j.psym.2013.09.004.

Wu, Q., \& Kling, J. M. (2016). Depression and the Risk of Myocardial Infarction and Coronary Death. Medicine (United
States), 95(6), 1-9. https://doi.org/10.1097/ MD.0000000000002815.

Yaacob, N. R. N. (2013). Cognitive Therapy Approach from Islamic Psychospiritual Conception. Procedia - Social and Behavioral Sciences, 97, 182-187. https:// doi.org/10.1016/j.sbspro.2013.10.220. 